\title{
DIET OF THE EXOTIC AMERICAN BULLFROG, LITHOBATES CATESBEIANUS, IN A STREAM OF NORTHWESTERN BAJA CALIFORNIA, MEXICO
}

\author{
Liliana Ortíz-Serrato ${ }^{1}$, Gorgonio Ruiz-Campos ${ }^{1,2}$, and Jorge H. Valdez-Villavicencio ${ }^{3}$
}

\begin{abstract}
We studied the diet of the exotic American bullfrog (Lithobates catesbeianus) in Arroyo San Carlos, located in northwestern Baja California, Mexico, during spring and summer 2009. Analysis of 64 stomach contents revealed 15 prey types, of which the exotic red crayfish (Procambarus clarkii) and terrestrial isopods (Armadillidiidae) were the most significant items (according to an index of their relative importance), making up $64 \%$ and $31 \%$ of the bullfrog's diet, respectively. Diet differed between the sexes, with red crayfish eaten more frequently by males $(84 \%)$ than females $(69 \%)$. Bullfrog diet changed with body size, with smaller individuals $(\leq 86 \mathrm{~mm})$ containing woodlice $(61 \%)$ as the dominant prey type and larger individuals $(\geq 129 \mathrm{~mm})$ containing red crayfish $(97 \%)$ as the dominant prey type. The average prey size consumed was significantly correlated with body length.
\end{abstract}

RESUMEN-Estudiamos la dieta de la rana toro americana exótica (Lithobates catesbeianus) del Arroyo San Carlos, noroeste de Baja California, México, durante la primavera y verano de 2009. Análisis de 64 contenidos estomacales revelaron 15 tipos de presas, de los cuales el langostino rojo exótico (Procambarus clarkii) y el isópodo terrestre (Armadilliidae) fueron las presas más significativas en términos del índice de importancia relativa, con $64 \%$ y $31 \%$ de su dieta, respectivamente. La dieta fue diferente entre sexos siendo el langostino rojo (84\%) más frecuentemente consumido en los machos que en las hembras (69\%). La dieta de la rana toro cambió con la talla corporal, dominando los isópodos terrestres $(61 \%)$ en ejemplares $\leq 86 \mathrm{~mm}$ y los langostinos rojos $(97 \%)$ en ejemplares $\geq 129 \mathrm{~mm}$. El tamaño promedio de presa consumida por la rana toro presentó una correlación significativa con la longitud corporal.

The American bullfrog, Lithobates catesbeianus (Shaw, 1802), has the largest range of any North American amphibian and is reported to be native across most of the United States east of the Rocky Mountains to Nova Scotia and northeastern Mexico (Casper and Hendricks 2005). Over the past several decades, American bullfrogs (hereafter, also referred to as bullfrogs) have been introduced as a food resource in many areas throughout the world (Storer 1922, Moyle 1973, Bury and Whelan 1984, Giovanelli et al. 2008), including the western continental United States of America (California and Colorado), Hawaii, western Canada (Jancowski and Orchard 2013), northwestern Mexico, Caribbean islands, South America, Asia (Bury and Whelan 1984, Kupferberg 1997), and some European countries (Stumpel 1992, Thiesmeier et al. 1994). Bullfrogs have also been introduced to the northern region of Baja California (Grismer 2002, Mahrdt et al. 2002) and several oases of Baja California Sur (Grismer 2002, Luja and Rodríguez-Estrella 2010).
The American bullfrog is the largest frog in North America, reaching $185 \mathrm{~mm}$ in length (Blair 1957). This species establishes in new areas relatively easily due to its generalist diet, wide ecological plasticity, and high competitive capacity (Maeda and Matsui 1999), which also promotes the extirpation or decline of populations of native anurans (Moyle 1973, Hammerson 1982, Hayes and Jennings 1986, Lannoo et al. 1994, Rosen and Schwalbe 1995, Kupferberg 1997, Kiesecker and Blaustein 1998, Luja and Rodríguez-Estrella 2010).

Although bullfrogs have become established in some oases of the Baja California Peninsula (BCP) and are associated with the extirpation of native anurans in many of these oases (Luja and Rodríguez-Estrella 2010), no study has evaluated the diet composition of this exotic frog in the BCP. Thus, we analyzed the diet composition of the American Bullfrog during the spring and summer from an established population in northwestern Baja California, México, in order to provide information on its

\footnotetext{
${ }^{1}$ Laboratorio de Vertebrados. Facultad de Ciencias, Universidad Autónoma de Baja California, Km. 103 Carretera Tijuana-Ensenada, Ensenada, Baja California, 22860, México.

${ }^{2}$ Corresponding author. Cuerpo Académico Estudios Relativos a la Biodiversidad. Facultad de Ciencias, Universidad Autónoma de Baja California, Km. 103 Carretera Tijuana-Ensenada, Ensenada, Baja California,22860, México.E-mail: gruiz@uabc.edu.mx

${ }^{3}$ Conservación de Fauna del Noroeste, A.C., La Paz, Baja California Sur, 23205, México.
} 


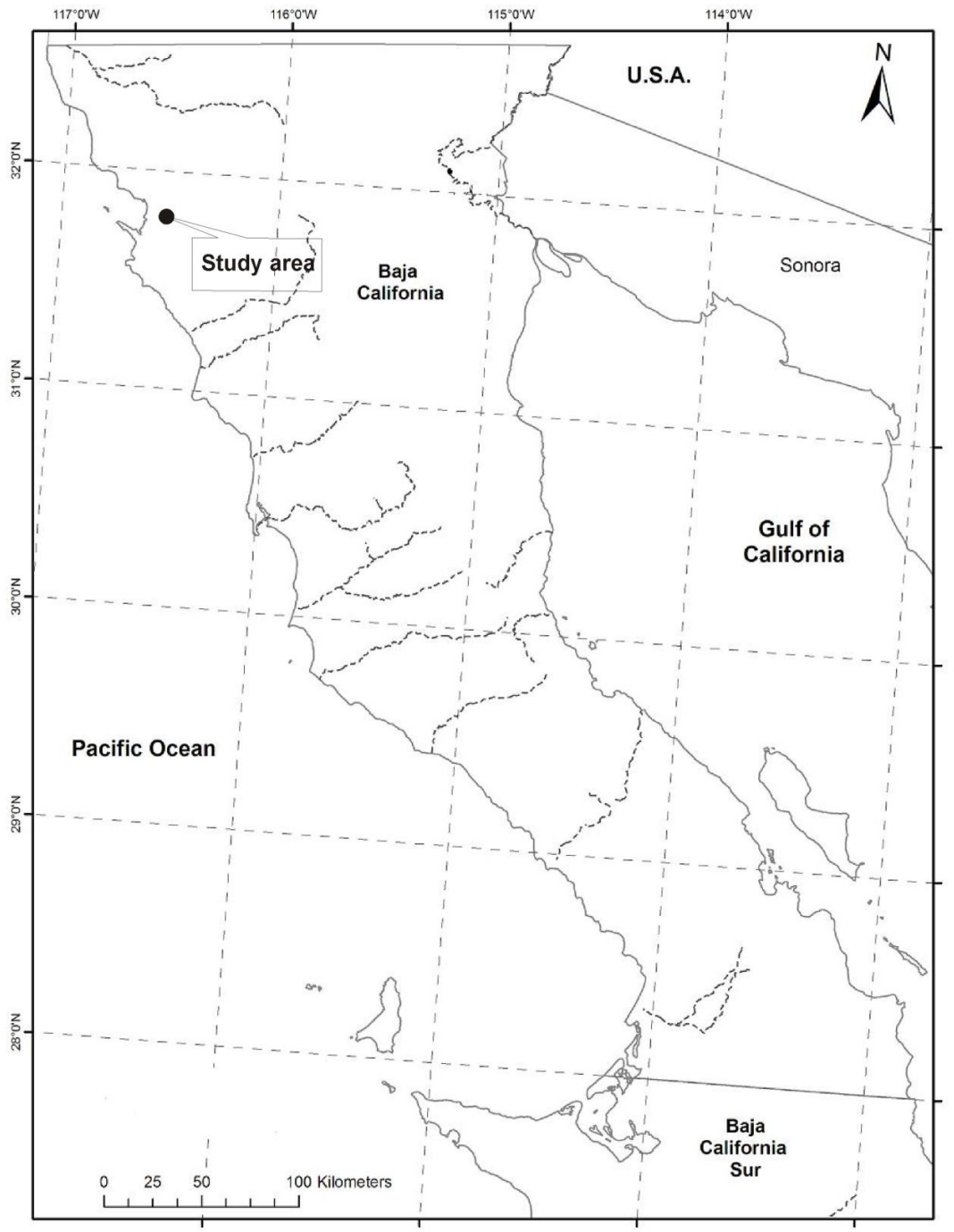

Fig. 1. Study area for the sampling of the American bullfrog, Lithobates catesbeianus, in the Arroyo San Carlos, northwest Baja California, Mexico.

feeding patterns and potential as a predator on native riparian and aquatic species.

\section{METHODS}

Arroyo San Carlos is located approximately $20 \mathrm{~km}$ southeast of Ensenada, Baja California, Mexico (Fig. 1). Arroyo San Carlos generally flows from east to west and drains into the Pacific Ocean. It is part of the Northwest Baja California Hydrological Region (RH1) and flows through the Maneadero Plain to connect with the Estero Punta Banda. The climate of the area is Mediterranean, with dry summers and rainy winters, mean annual temperatures of $12-18{ }^{\circ} \mathrm{C}$, and mean annual rainfall of $100-300$ $\mathrm{mm}$ (INEGI 2001). Riparian vegetation is represented by tree species such as Platanus racemosa, Populus fremontii, and Salix lasiolepis, as well as shrubs such as Baccharis salicifolia, Baccharis sarothroides, Salvia vaseyi, and Lonicera subspicata (Delgadillo 1997).

Bullfrogs were collected monthly (MayAugust 2009) along a 2-km segment of the Arroyo San Carlos between Las Hamacas $\left(31^{\circ}\right.$ $47^{\prime} 47.23^{\prime \prime} \mathrm{N}, 116^{\circ} 30^{\prime} 04.02^{\prime \prime} \mathrm{W}, 104 \mathrm{~m}$ asl) and Las Delicias $\left(31^{\circ} 47^{\prime} 55.46^{\prime \prime} \mathrm{N}, 116^{\circ} 29^{\prime} 17.39^{\prime \prime} \mathrm{W}\right.$, $122 \mathrm{~m}$ asl) ranches (Fig. 1). Spotlight sampling 
was conducted during evening and night, and frogs were captured by dip net. At each sampled site, we also measured temperature, conductivity, $\mathrm{pH}$, dissolved oxygen, salinity, and total dissolved solids at 4 points at intervals of $4 \mathrm{~m}$ by using a Hydrolab Scout 2 multianalyzer (Hydrolab Co., Austin, TX).

Each captured bullfrog was euthanized with $10 \%$ chloroform, weighed using a digital balance $( \pm 0.1 \mathrm{~g})$, sexed based on tympanum diameter (in males the tympanum is larger than the eye, whereas in females it is equal to or smaller than the eye; Álvarez-Romero et al. 2005). Juveniles were distinguished from adults by the presence of distinct inky black specks on the dorsal surface (Hallock and McAllister 2009). Snout-vent length (SVL) of each bullfrog was measured using a caliper $( \pm 0.01$ $\mathrm{mm})$. The stomach was removed from each specimen, weighed to the nearest $0.1 \mathrm{~g}$, fixed in $10 \%$ formalin for 8 days, rinsed, and stored in $50 \%$ isopropanol. Voucher specimens were deposited in the herpetological collection of the Universidad Autónoma de Baja California at Ensenada (CH-UABC).

Stomach contents were sorted, identified, and quantified under a stereoscopic microscope. Complete prey items were measured (body length) using an ocular micrometer adapted to the stereoscopic microscope. The importance of each prey item in the diet was determined using the index of relative importance (IRI-Pinkas et al. 1971), which combines the contribution of each prey item in the diet in terms of number, weight, and frequency of occurrence (Hyslop 1980, Garvey and Chipps 2012). This integrative index is calculated as follows:

$$
\mathrm{IRI}_{i}=\left(\% \mathrm{~N}_{i}+\% \mathrm{~W}_{i}\right) \times \% \mathrm{FO}_{i},
$$

where $\% \mathrm{~N}_{i}=($ total number of prey $i) /($ number of all identifiable prey in all the stomachs) $\times 100 ; \% \mathrm{~W}_{j}=$ (total wet weight of prey $i$ )/ (total wet weight of all identifiable prey in all the stomachs $) \times 100$; and $\% \mathrm{OF}_{i}=$ (number of stomachs with prey $i$ )/(number of stomachs with content analyzed) $\times 100$ (Lagler 1978). For comparative purposes, the absolute value of IRI for each prey taxa was expressed as the percentage of the total sum of IRI for all prey taxa. This \%IRI was used to analyze the diet composition as a function of time (month), sex, and SVL.
Three size classes (SVL) were selected based on the ranges of frequency of sizes for the different age cohorts present (Jancowsky and Orchard 2013): size class 1 -juveniles, $\leq 86 \mathrm{~mm}$; size class 2-young adults, $87-128 \mathrm{~mm}$; and size class 3 -mature adults, $>128 \mathrm{~mm}$. Juveniles were individuals in their first year postmetamorphosis, whereas young adults and mature adults were those in their second and third year post-metamorphosis, respectively (Jancowsky and Orchard 2013). Tadpoles were not considered in this study.

The proportions of the prey items $\left(\% \mathrm{IRI}_{i}\right)$ for bullfrogs among groups (months, sexes, or size classes) were compared using contingency tables $\left(\chi^{2}\right)$, with a level of significance $(\alpha)$ of 0.05 (Zar 1999). In those cases when the independence hypothesis was rejected in the first test, the groups were compared in a pairwise manner in order to find the group explaining the highest difference.

Pearson's correlation coefficient was calculated to determine whether the average size of prey consumed by bullfrogs is associated with bullfrog body length (SVL) or stomach volume.

\section{REsults}

The ranges of the different physicochemical parameters of the water in the studied sites were as follows: temperature, $19.5^{\circ} \mathrm{C}$ (May) to $29{ }^{\circ} \mathrm{C}$ (August); conductivity, $0.57 \mathrm{mS} \cdot \mathrm{cm}^{-1}$ (August) to $1.70 \mathrm{mS} \cdot \mathrm{cm}^{-1}$ (July); $\mathrm{pH}, 7.6$ (May) to 9.7 (August); dissolved oxygen, 3.07 $\mathrm{mg} \cdot \mathrm{L}^{-1}$ (August) to $7.01 \mathrm{mg} \cdot \mathrm{L}^{-1}$ (May); salinity, $0.3 \mathrm{ppt}$ (August) to $0.9 \mathrm{ppt}$ (July); and total dissolved solids, $0.34 \mathrm{~g} \cdot \mathrm{L}^{-1}$ (August) to $1.08 \mathrm{~g} \cdot \mathrm{L}^{-1}$ (July).

Sixty-four American bullfrogs $(45-170 \mathrm{~mm}$ SVL; 20 males, 27 females, and 17 juveniles or unknown sex) were collected. Fifteen prey types were identified, including 10 families of insects, 2 crustaceans of the families Cambaridae (red crayfish, Procambarus clarkii) and Armadillidiidae (woodlice), one American bullfrog, one arachnid, and one bivalve (Table 1). Based on $\% \operatorname{IRI}_{i}$, the most representative prey items (both sexes combined) were the red crayfish with $64 \%$ and woodlice with $31 \%$ (Table 1).

Diet composition of all collected specimens changed across months, with red crayfish dominating in May (69\%), June (42\%), and July $(85 \%)$ and woodlice $(65 \%)$ dominating in 
TABLE 1. Diet composition of American bullfrog, Lithobates catesbeianus, $(n=64)$ from Arroyo San Carlos, Ensenada, Baja California, Mexico, from May to August 2009. NP = number of measured complete prey, Mean $\mathrm{W}=$ mean weight (g), $\% \mathrm{OF}=$ percentage of occurrence frequency, $\% \mathrm{~N}=$ numerical percentage, $\% \mathrm{~W}=$ weight percentage, IRI $=$ index of relative importance, and \% IRI = percentage of the index of relative importance.

\begin{tabular}{lrlrrrrr}
\hline Prey item & $\mathrm{NP}$ & $\mathrm{W}(\mathrm{g})$ & $\% \mathrm{OF}$ & $\% \mathrm{~N}$ & $\% \mathrm{~W}$ & $\mathrm{IRI}$ & $\% \mathrm{IRI}$ \\
\hline Procambarus clarkii & 26 & 5.39 & 29.69 & 16.77 & 82.35 & 2942.9 & 63.66 \\
Curculionidae & 3 & 0.01 & 4.69 & 1.94 & 0.17 & 9.9 & 0.21 \\
Forficulidae & 17 & 0.21 & 9.38 & 10.97 & 2.12 & 122.8 & 2.66 \\
Scarabaeidae & 2 & 0.11 & 3.13 & 1.29 & 0.13 & 4.4 & 0.10 \\
Gomphidae & 4 & 1.76 & 4.68 & 2.58 & 4.14 & 31.4 & 0.68 \\
Armadillidiidae & 80 & 0.1 & 25.00 & 51.61 & 4.93 & 1413.5 & 30.58 \\
Hidrophilidae & 2 & 0.54 & 3.13 & 1.29 & 0.64 & 6.0 & 0.13 \\
Apidae & 8 & 0.12 & 9.38 & 5.16 & 0.56 & 53.7 & 1.16 \\
Formicidae & 4 & 0.3 & 4.69 & 2.58 & 0.70 & 15.4 & 0.33 \\
Tenebrionidae & 2 & 1.15 & 1.56 & 1.29 & 1.35 & 4.1 & 0.09 \\
Carabidae & 3 & 0.1 & 4.69 & 1.94 & 0.18 & 9.9 & 0.22 \\
Lithobates catesbeianus & 1 & 2.9 & 1.56 & 0.65 & 1.7 & 3.7 & 0.08 \\
Vespinae & 1 & 0.02 & 1.56 & 0.65 & 0.01 & 1.0 & 0.02 \\
Bivalvia & 1 & 1.0 & 1.56 & 0.65 & 0.58 & 1.9 & 0.04 \\
Arachnida & 1 & 0.73 & 1.56 & 0.65 & 0.43 & 1.7 & 0.04 \\
\hline
\end{tabular}

TABLE 2. Index of relative importance (\%IRI) of prey consumed by American bullfrog, Lithobates catesbeianus, in the Arroyo San Carlos, northwestern Baja California (May-August 2009), by month, sex, and size class. Bolded values within columns identify the prey types that cumulatively contribute at least $70 \%$ to diet composition.

\begin{tabular}{|c|c|c|c|c|c|c|c|c|c|c|}
\hline \multirow[b]{2}{*}{ Prey item } & \multicolumn{4}{|c|}{ Month } & \multicolumn{3}{|c|}{ Sex } & \multicolumn{3}{|c|}{ Size class $(\mathrm{mm})$} \\
\hline & May & Jun & Jul & Aug & $\hat{0}$ & q & Unkn. & $\leq 86$ & $87-128$ & $>128$ \\
\hline Procambarus clarkii & 68.6 & 42.0 & 85.0 & 22.9 & 83.9 & 68.9 & 9.6 & 10.0 & 40.8 & 96.8 \\
\hline Curculionidae & 0.9 & 1.8 & 0.0 & 0.0 & 0.0 & 0.4 & 0.3 & 0.0 & 0.3 & 0.3 \\
\hline Forficulidae & 18.3 & 5.4 & 0.0 & 0.0 & 8.9 & 0.3 & 3.5 & 0.0 & 6.3 & 0.3 \\
\hline Scarabaeidae & 0.2 & 1.7 & 0.0 & 0.0 & 0.36 & 0.1 & 0.0 & 0.0 & 0.0 & 0.3 \\
\hline Gomphidae & 0.4 & 0.0 & 0.0 & 6.1 & 0.0 & 0.0 & 16.0 & 8.0 & 1.4 & 0.0 \\
\hline Armadillidiidae & 11.0 & 37.1 & 9.1 & 64.5 & 3.9 & 28.4 & 66.0 & 73.9 & 47.9 & 0.3 \\
\hline Hidrophilidae & 0.2 & 0.0 & 0.0 & 0.2 & 0.0 & 0.0 & 1.1 & 1.4 & 0.2 & 0.0 \\
\hline Apidae & 0.0 & 0.0 & 5.2 & 2.2 & 2.15 & 0.6 & 0.3 & 0.0 & 2.4 & 0.0 \\
\hline Formicidae & 0.0 & 3.3 & 0.0 & 1.7 & 0.0 & 0.2 & 2.2 & 1.2 & 0.2 & 0.6 \\
\hline Tenebrionidae & 0.0 & 0.0 & 0.0 & 1.5 & 0.0 & 0.4 & 0.0 & 0.0 & 0.3 & 0.0 \\
\hline Carabidae & 0.0 & 7.2 & 0.0 & 0.2 & 0.0 & 0.4 & 0.2 & 0.0 & 0.3 & 0.3 \\
\hline $\begin{array}{l}\text { Lithobates } \\
\quad \text { catesbeianus }\end{array}$ & 0.0 & 0.0 & 0.8 & 0.0 & 0.78 & 0.0 & 0.0 & 0.0 & 0.0 & 0.5 \\
\hline Vespinae & 0.0 & 1.5 & 0.0 & 0.0 & 0.0 & 0.1 & 0.0 & 0.0 & 0.0 & 0.3 \\
\hline Bivalvia & 0.0 & 0.0 & 0.0 & 0.7 & 0.0 & 0.0 & 0.8 & 5.5 & 0.0 & 0.0 \\
\hline Arachnida & 0.3 & 0.0 & 0.0 & 0.0 & 0.0 & 0.2 & 0.0 & 0.0 & 0.0 & 0.3 \\
\hline Number of stomachs & 17 & 14 & 17 & 16 & 20 & 27 & 17 & 10 & 28 & 26 \\
\hline
\end{tabular}

August $\left(\chi^{2}=218.8, \mathrm{df}=42, P<0.001\right)$. The highest difference in diet was found between the summer months of July and August $\left(\chi^{2}=\right.$ 93, $\mathrm{df}=9, P<0.001)$.

The diet also differed between sexes (Table $2 ; \chi^{2}=172$, df $\left.=28, P<0.001\right)$. Females $(n=27)$ consumed both red crayfish $(69 \%)$ and woodlice $(28 \%)$, whereas males $(n=20)$ showed a notable consumption of red crayfish $(84 \%)$ and earwigs (9\%). In the case of juveniles $(n=17)$ whose gender was not determined, woodlice (62\%) and dragonflies (Gomphidae, 18\%) made up the majority of their diet. The highest difference in diet was found between juveniles and males $\left(\chi^{2}=138\right.$, df $=$ $11, P<0.001)$.

The comparison of diet composition among the 3 size classes also revealed differences in the proportions of prey items consumed $\left(\chi^{2}=\right.$ $189, \mathrm{df}=28, P<0.001)$. Size classes 1 and 3 showed the highest difference in the diet $\left(\chi^{2}\right.$ $=158, \mathrm{df}=12, P<0.001)$. The prey item consumed most frequently by size class 1 was woodlice $(74 \%)$, whereas both woodlice $(48 \%)$ and red crayfish $(41 \%)$ were similarly consumed by individuals of size class 2 . However, 

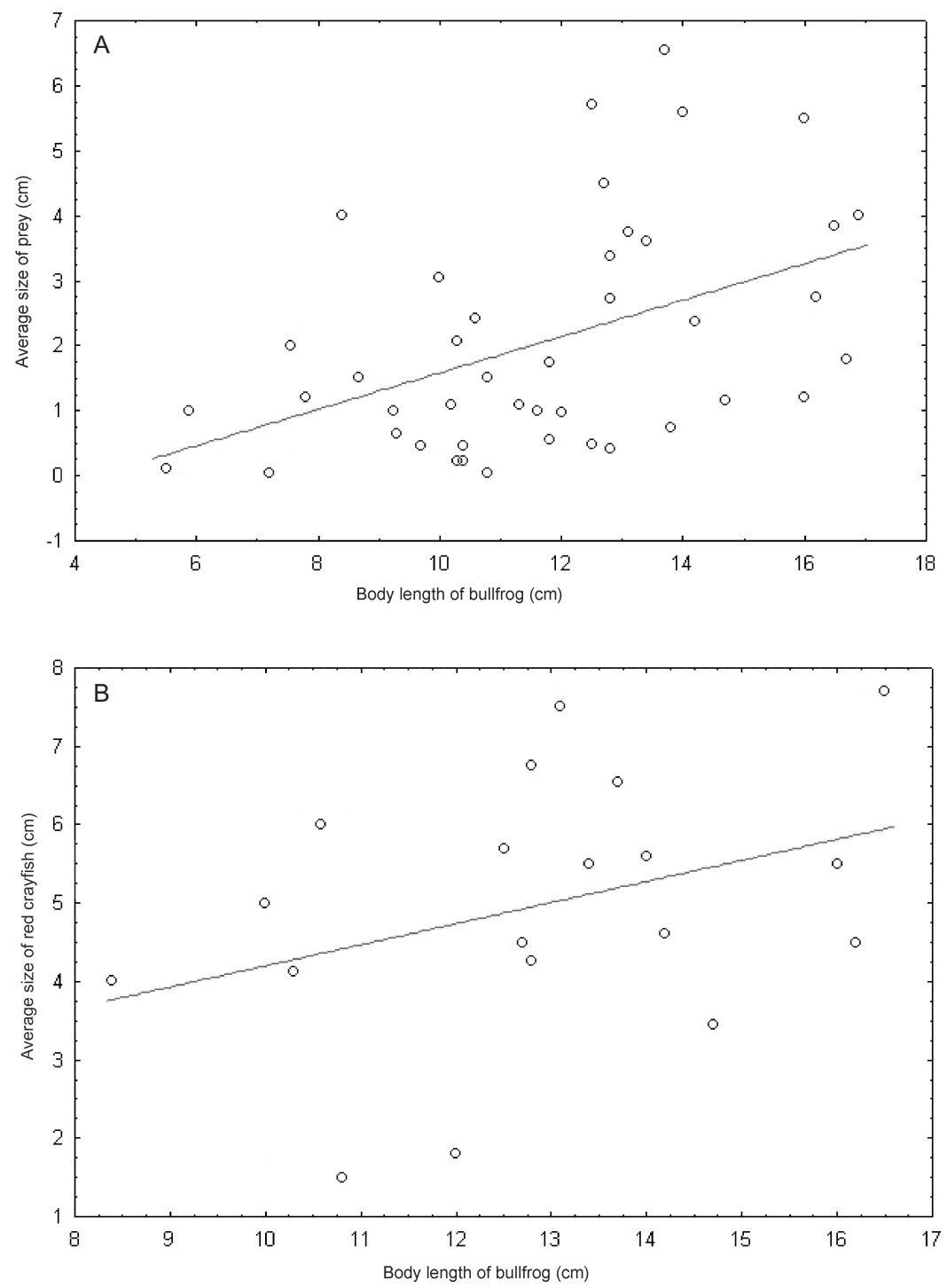

Fig. 2. Relationship between average size of consumed prey and body length (SVL) of American bullfrogs in the Arroyo San Carlos, Baja California, Mexico: (A) all prey taxa combined, $Y=-1.2152+0.2798 * X, r=0.46, P<0.05$; (B) red crayfish, $Y=1.5087+0.2692 * X ; r=0.36, P<0.05)$.

red crayfish was the prey item dominating $(97 \%)$ the diet composition of size class 3 (Table 2).

There was a significant increase in prey size consumed with increased bullfrog SVL $(Y$ $=-1.2152+0.2798 * X ; n=43, r=0.46, P$ $<0.05$; Fig. 2A). Likewise, there was a significant increase in size of the most common prey (red crayfish) with increased bullfrog SVL $(Y$ $=1.5087+0.2692 * X ; n=19, r=0.36, P<$ 0.05 ; Fig. $2 B$ ). Finally, the wet mass of stomach contents significantly increased with bullfrog SVL $(W=-10.822+1.833 * X ; n=64, r=$ $0.63, P<0.05)$.

\section{Discussion}

The diet of the invasive American bullfrog in the Arroyo San Carlos (northwestern Baja California) in the spring and summer months was primarily composed of exotic red crayfish (Procambarus clarkii) and woodlice (terrestrial 
isopods). The dominance of red crayfish in the diet of bullfrogs has also been reported for other regions of the bullfrog's nonnative distribution (Clarkson and deVos 1986, Hirai 2004).

The diet composition in our study revealed differences among sampling months, sexes, and size classes. Hirai (2004) found a high dominance of red crayfish in the diet of adult bullfrogs but with little variation from May to August. Although the feeding spectrum of the bullfrog differed between adult males and females, both shared a high proportion of red crayfish, as reported by Werner et al. (1995) and Silva et al. (2009); in contrast, juveniles had a diet based mainly on woodlice and dragonflies. A greater preference for red crayfish allows adult bullfrogs to take advantage of this prey's large size, high energetic content, and high availability (Townsend and Winfield 1985, Gerking 1994), whereas juvenile bullfrogs tend to consume smaller prey of terrestrial origin (woodlice, dragonflies) that are more easily captured in the riparian zone. These diet differences between adults and juveniles might be due to partitioning of foraging habitat and prey size as a way of reducing competition (Schoener 1974). The increase in prey size with bullfrog body length (SVL) reported here is similar to reports by Werner et al. (1995), Wu et al. (2005), and Silva et al. (2009).

No native anurans (e.g., Pseudacris hypochondriaca, Anaxyrus californicus, and Rana draytonii) that are known to occur in the area of the study site were found in bullfrog stomach contents. Although these 3 native anurans are found in the streams of northwestern Baja California (Grismer 2002), their absence in the studied sites might be the result of competitive exclusion by American bullfrogs, a situation that is known to occur in other areas of the bullfrog's nonnative distribution (Moyle 1973, Smith 1977, Kiesecker and Blaustein 1998, Silva et al. 2009, 2011, Jancowsky and Orchard 2013). One individual contained the remains of another bullfrog, representing a low frequency of cannibalism, similar to findings reported by Stuart and Painter (1993) and Jancowsky and Orchard (2013).

In summary, diet composition of the exotic American bullfrog in the Arroyo San Carlos in northwestern Baja California is mainly represented by introduced red crayfish in adults and by terrestrial isopods in juveniles. In future research, efforts should be made to simultaneously quantify the diet composition of the American bullfrog and measure the prey availability in the environment (both aquatic and riparian). Such studies would reveal more about the bullfrog's feeding strategy in relation to the abundance of available prey items. Though no native anurans were found in the gut contents from bullfrogs in Arroyo San Carlos, their absence may be due to the exclusion of native frogs from the localized habitats where bullfrogs occur.

\section{ACKNOWLEDGMENTS}

We thank Sergio Sánchez, Andrea Navarro, Adriana Mateos, Israel Hernández, and Germán Ruiz for helping us with the field sampling. This study was partially supported by the Universidad Autónoma de Baja California (project 213 "Evaluación Ecológica y Distribución de Especies Exóticas Invasivas Selectas en Humedales del Estado de Baja California"). Sebastiano Salvidio, Bradford D. Hollingsworth, Jaime Zúñiga-Vega, and one anonymous reviewer made very useful comments that improved the content and clarity of the manuscript.

\section{Literature Cited}

Álvarez-Romero, J., R.A. Medellín, H. Gómez DE Silva, and A. Oliveras de Ita. 2005. Ficha técnica de Rana catesbeiana. In: R. Medellín, compiler, Vertebrados superiores exóticos en México: diversidad, distribución y efectos potenciales. Instituto de Ecología, Universidad Nacional Autónoma de México, Bases de datos SNIB-CONABIO, México.

Blair, A.P. 1957. Amphibians. Pages 213-271 in W.F. Blair, A.P. Blair, P. Brodkorb, F.R. Cagle, and G.A. Moore, editors, Vertebrates of the United States. McGraw-Hill, New York, NY.

Bury, R.B., AND J.A. WheLAn. 1984. Ecology and management of the bullfrog. U.S. Fish and Wildlife Service Resource Publication 155, USFWS, Washington, DC.

Casper, G.S., And R. Hendricks. 2005. Rana catesbeiana Shaw, 1802: American bullfrog. Pages 540-546 in M. Lannoo, editor, Amphibian declines: the conservation status of United States species. University of California Press, Berkeley and Los Angeles, CA.

Clarkson, R.W., and J.C. DEVos Jr. 1986. The bullfrog, Rana catesbeiana Shaw, in the Lower Colorado River, Arizona-California. Journal of Herpetology 20:42-49.

Delgadillo, J. 1997. Florística y ecología del norte de Baja California. 2nd edition. Universidad Autónoma de Baja California, México.

Garvey, J.E., AND S.R. ChipPs. 2012. Diets and energy flow. Pages 733-779 in A.V. Zale, D.L. Parrish, and 
T.M. Sutton, editors, Fisheries techniques. 3rd edition. American Fisheries Society, Bethesda, MD.

Gerking, S.D. 1994. Feeding ecology of fish. Academic Press, San Diego, CA.

Giovanelli, J.G.R., C.F.B. Haddad, and J. Alexandrino. 2008. Predicting the potential distribution of the alien invasive American bullfrog (Lithobates catesbeianus) in Brazil. Biological Invasions 10:585-590.

Grismer, L.L. 2002. Amphibians and reptiles of Baja California, including its Pacific islands and the islands in the Sea of Cortés. University of California Press, Berkeley, CA.

Hallock, L.A., AND K.R. McAlLister. 2009. American bullfrog. Washington Herp Atlas. [Cited 30 September 2013]. Available from: http://wwwl.dnr.wa.gov/ nhp/refdesk/herp/.

Hammerson, G.A. 1982. Bullfrog eliminating leopard frogs in Colorado? Herpetological Review 13:115-116.

Hayes, M.P., and M.R. Jennings. 1986. Decline of ranid frog species in western North America: are bullfrogs (Rana catesbeiana) responsible? Journal of Herpetology 20:490-509.

Hirai, T. 2004. Diet composition of introduced bullfrog, Rana catesbeiana, in the Mizorogaike Pond of Kyoto, Japan. Ecological Research 19:375-380.

HysLOP, E.J. 1980. Stomach contents analysis: a review of methods and their application. Journal of Fish Biology 17:411-429.

[INEGI] Instituto Nacional de Estadística y GeOGRAFÍA. 2001. Síntesis de Información Geográfica del Estado de Baja California. México. ISBN: 970-133200-8.

JanCOWski, K., and S.A.OrChard. 2013. Stomach contents from invasive American bullfrogs Rana catesbeiana (= Lithobates catesbeianus) on southern Vancouver Island, British Columbia, Canada. NeoBiota 16:17-37.

Kiesecker, J.M., And A.R. Blaustein. 1998. Effects of introduced bullfrogs and smallmouth bass on the microhabitat use, growth and survival of native redlegged frogs. Conservation Biology 12:776-787.

KupferberG, S.J. 1997. Bullfrog (Rana catesbeiana) invasion of a California river: the role of larval competition. Ecology 78:1736-1751.

LAGLER, K.F. 1978. Freshwater fishery biology. Wm. C. Brown Co., Dubuque, IA.

Lannoo, M.J., K. Lang, T. Waltz, and G.S. Phillips. 1994. An altered amphibian assemblage: Dickinson County, Iowa, 70 years after Frank Blanchard's survey. American Midland Naturalist 131:311-319.

Luja, V.H., AND R. Rodríguez-EstrelLa. 2010. The invasive bullfrog Lithobates catesbeianus in oases of Baja California Sur, Mexico: potential effects in a fragile ecosystem. Biological Invasions 12:2979-2983.

Maeda, N., And M. Matsui. 1999. Frogs and toads of Japan. 2nd edition. Bun-Ichi Sogo Shuppan Co., Ltd., Tokyo, Japan.

Mahrdt, C.R., R.E. Lovich, and S.J. Zimmitti. 2002. Natural history notes. Bufo californicus (California arroyo toad), habitat and population status. Herpetological Review 33:123-125.

Moyle, P.B. 1973. Effects of introduced bullfrogs, Rana catesbeiana, on the native frogs of the San Joaquin Valley, California. Copeia 1973:18-22.
Pinkas, L., M.S. Oliphant, and I.L.K. Inverson. 1971. Food habits of albacore, bluefin tuna and bonito in California waters. California Department of Fish and Game, Fish Bulletin 152:1-105.

Rosen, P.C., and P.R. Schwalbe. 1995. Bullfrogs: introduced predators in southwestern wetlands. Pages 452-453 in E.T. La-Roe, G.S. Farris, C.E. Puckett, P.D. Doran, and M.J. Mac, editors, Our living resources: a report to the nation on the distribution, abundance, and health of U.S. plants, animals, and ecosystems. U.S. Department of the Interior, National Biological Service, Washington, DC.

Schoener, T.W. 1974. Resource partitioning in ecological communities. Science 185:27-39.

Silva, E.T., E. Pinhero Dos-Reis, and R. Neves-Feio. 2009. Diet of the invasive frog Lithobates catesbeianus (Shaw, 1802) (Anura: Ranidae) in Viçosa, Minas Gerais State, Brazil. South American Journal of Herpetology 4:286-294.

Silva, E.T., O. Pinto-Ribeiro, and R. Neves-Feio. 2011. Predation of native anurans by invasive bullfrogs in southeastern Brazil: spatial variation and effect of microhabitat use by prey. South American Journal of Herpetology 6:1-10.

SMITH, A.K. 1977. Attraction of bullfrogs (Amphibia, Anura, Ranidae) to distress calls of immature frogs. Journal of Herpetology 11:234-235.

Storer, T.I. 1922. The eastern bullfrog in California. California Fish and Game 8:219-224.

Stuart, J.N., And C.W. Painter. 1993. Rana catesbeiana (bullfrog). Cannibalism. Herpetological Review 24: 103.

STUMPEL, A.H.P. 1992. Successful reproduction of introduced bullfrogs, Rana catesbeiana, in northwestern Europe: a potential threat to indigenous amphibians. Biological Conservation 60:61-62.

Thiesmeier B., O. Jäger, And U. Fritz. 1994. Erfolgreiche Reproduktion des Ochsenfrosches (Rana catesbeiana) im nördlichen Landkreis Böblingen (BadenWürttemberg). Zeitschrift für Feldherpetologie 1: $169-176$.

Townsend, C.R., And I.J. WinfiELD. 1985. The application of optimal foraging theory to feeding behaviour in fish. Pages: 67-98 in P. Tytler and P. Calow, editors, Fish energetics: new perspectives. Johns Hopkins University Press, Baltimore, MD.

Werner, E.E., G.A. Wellborn, and M.A. McPeek. 1995. Diet composition in postmetamorphic bullfrogs and green frogs: implications for interspecific predation and competition. Journal of Herpetology 29: 600-607.

Wu, Z., Y. LI, Y. WANG, AND M.J. Adams. 2005. Diet of introduced bullfrogs (Rana catesbeiana): predation on and diet overlap with native frogs on Daishan Island, China. Journal of Herpetology 39:668-674.

ZaR, H.J. 1999. Biostatistical analysis. Prentice Hall, Upper Saddle River, NJ.

Received 10 May 2013

Accepted 20 December 2013 